\title{
Determinan Penerapan Akuntansi Pertanggungjawaban Terhadap Pengendalian Biaya Pada Badan Layanan Umum Rumah Sakit Umum Daerah Manokwari
}

\author{
Simson Werimon ${ }^{1}$, Mona P. Mokodompit ${ }^{1}$, Subekti Catur Oktarisa \\ ${ }^{1}$ Program Studi Akuntansi, Universitas Papua
}

Received: November 2019; Accepted: Januari 2020; Published: Maret 2020

\begin{abstract}
Abstrak
Penelitian ini bertujuan untuk mengetahui penerapan Struktur Organisasi, Perencanaan Anggaran, Pelaksanaan Pengendalian, Pelaporan dalam Akuntansi Pertanggungjawaban berpengaruh signifikan terhadap Pengendalian Biaya. Variabel Independen dalam penelitian ini adalah Struktur Organisasi, Perencanaan Anggaran, Pelaksanaan Pengendalian, Pelaporan. Sedangkan variabel dependennya adalah Pengendalian Biaya. Populasi dalam penelitian ini adalah Direktur, Kepala Bidang Keuangan, Seksi Verifikasi dan Akuntansi, Seksi Perbendaharaan dan Anggaran, dan Staf Administrasi berjumlah 66 orang. Teknik pengambilan sampel yang digunakan adalah metode sampling jenuh atau sensus. Data yang digunakan dalam penelitian ini adalah data primer yang diperoleh secara langsung melalui cara menyebar kuesioner kepada responden. Hasil uji penelitian ini menunjukkan bahwa Struktur Organisasi dan Pelaporan berpengaruh signifikan terhadap Pengendalian Biaya. Sedangkan Perencanaan Anggaran dan Pelaksanaan Pengendalian tidak berpengaruh terhadap Pengendalian Biaya.
\end{abstract}

Kata kunci: struktur organisasi, perencanaan anggaran, pelaporan dan pengendalian biaya

\begin{abstract}
This study aims to determine the application of Organizational Structure, Budget Planning, Control Implementation, Reporting in Accountancy Accounting has a significant effect on Cost Control. Independent variables in this study are Organizational Structure, Budget Planning, Implementation of Control, Reporting. While the dependent variable is Cost Control. The population in this study were the Director, Head of Finance, Verification and Accounting Section, Treasury and Budget Section, and Administrative Staff totaling 66 people. The sampling technique used is the method of saturation sampling or census. The data used in this study are primary data obtained directly by means of spreading questionnaires to respondents. The test results of this study indicate that the Organizational Structure and Reporting have a significant effect on Cost Control. While Budget Planning and Implementation of Control does not affect the Cost Control.
\end{abstract}

Keywords: organizational structure, budget planning, Reporting and cost control

How to Cite: Werimon, dkk. (2020). Determinan Penerapan Akuntansi Pertanggungjawaban Terhadap Pengendalian Biaya Pada Badan Layanan Umum Rumah Sakit Umum Daerah Manokwari. JFRES: Journal of Fiscal and Regional Economy Studies, 3(1), 10 - 21 


\section{PENDAHULUAN}

Peraturan Pemerintah Nomor 23 Tahun 2005 dan Peraturan Menteri Dalam Negeri Nomor 61 Tahun 2007 tentang pengelolaan keuangan pada Badan Layanan Umum menjelaskan bahwa semua jenis layanan umum pemerintah harus berubah statusnya menjadi BLU/BLUD. Peraturan Pemerintah No. 23 tahun 2005 Pasal 1 Ayat 1 menjelaskan bahwa Badan Layanan Umum yang selanjutnya disebut BLU, adalah instansi di lingkungan Pemerintah yang dibentuk untuk memberikan pelayanan kepada masyarakat berupa penyediaan barang dan/atau jasa yang dijual tanpa mengutamakan mencari keuntungan dan dalam melakukan kegiatannya didasarkan pada prinsip efisiensi dan produktivitas. Jenis BLU disini adalah rumah sakit, lembaga pendidikan, pelayanan lisensi, penyiaran, dan lain-lain. Peraturan Pemerintah No. 23 Tahun 2005 dan Permendagri No. 61/2007 menjadi landasan hukum bagi BLU salah satunya Rumah Sakit Pemerintah untuk lebih otonom dibidang keuangan.

Rumah sakit sebagai salah satu jenis BLU merupakan ujung tombak dalam pembangunan kesehatan masyarakat. Rumah Sakit Pemerintah merupakan unit kerja dari Instansi Pemerintah yang memberikan pelayanan kesehatan kepada masyarakat umum. Dengan perubahan sistem keuangan rumah sakit serta sistem keuangan pemerintah, secara keseluruhan diharapkan dana yang dikelola oleh rumah sakit akan menjadi lebih besar dan terus meningkat sejalan dengan peningkatan penerimaan negara bukan pajak (PNBP). Kondisi ini selain akan membawa pengaruh positif bagi peningkatan pelayanan, tetapi juga membuka peluang untuk timbulnya akses negatif penyalahgunaan dalam pengelolaan keuangan negara, untuk itu diperlukan berbagai upaya dalam mengatasinya (Sufrin, 2017).

Rumah Sakit sebagai badan layanan umum yang menerapkan akuntansi pertanggungjawaban akan membentuk pusatpusat pertanggungjawaban. Menurut Samryn (2012:259) "Pusat pertanggungjawaban merupakan suatu bagian dalam organisasi yang memiliki kendali atas terjadinya biaya, perolehan pendapatan, atau penggunaan dana investasi. Keseluruhan pusat pertanggungjawaban ini membentuk jenjang hirarki dalam organisasi tersebut". Pusat pertanggungjawaban merupakan unit divisi yang dipimpin oleh kepala bagian divisi yang bertanggungjawab atas seluruh kegiatan yang ada pada divisi yang dipimpinnya. Setiap unit divisi menyusun program dan anggaran sampai melakukan penyusunan laporan pertanggungjawaban.

Menurut Setiyanto (2017), Akuntansi pertanggungjawaban dalam penerapannya mempunyai syarat-syarat antara lain: struktur organisasi, perencanaan anggaran, pelaksanaan pengendalian dan pelaporan. Juita (2014) menjelaskan bahwa struktur organisasi adalah struktur yang harus mengambarkan aliran tanggung jawab, wewenang dan posisi yang jelas untuk setiap unit kerja dari setiap manajemen. Selain itu, harus menggambarkan pembagian tugas dengan jelas. Dimana organisasi disusun sedemikian rupa sehingga wewenang mengalir dari tingkat manajemen dari atas ke bawah, sesuai tanggung jawab. Supriyono (1999) mendefinisikan anggaran sebagai suatu rencana terperinci yang dinyatakan secara formal biasanya dalam satuan uang untuk menunjukkan perolehan dan penggunaan sumber-sumber suatu organisasi dalam jangka waktu tertentu, biasanya dalam waktu satu tahun. Aliu (2013) menjelaskan pengendalian adalah sebagai monitoring dan evaluasi secara terus-menerus serta membandingkan antara anggaran dan realisasinya. Laporan pertanggungjawaban merupakan laporan-laporan yang menerangkan hasil dari konsep akuntansi pertanggungjawaban yang memegang peranan penting dalam kegiatan penyusunan perencanaan dan pengawasan atas jalannya operasi organisasi/perusahaan (Subramanyam dan Wild, 2010).

Perkembangan pengelolaan Rumah Sakit, baik dari aspek manajemen maupun operasional sangat dipengaruhi oleh berbagai tuntutan dari lingkungan, yaitu antara lain bahwa rumah sakit dituntut untuk memberikan pelayanan kesehatan yang bermutu dan biaya pelayanan kesehatan terkendali sehingga akan berujung pada kepuasan pasien. Tuntutan lainnya adalah pengendalian biaya. Pengendalian biaya merupakan masalah yang kompleks karena dipengaruhi oleh berbagai pihak yaitu mekanisme pasar, tindakan ekonomis, sumberdaya manusia yang dimiliki (profesionalitas) dan tidak kalah penting adalah perkembangan teknologi dari Rumah Sakit itu 
sendiri. Pengendalian biaya adalah perbandingan kinerja aktual dengan kinerja standar, penganalisaan selisih-selisih yang timbul guna mengidentifikasikan penyebab-penyebab yang dapat dikendalikan dan pengambilan tindakan untuk membenahi atau menyesuaikan perencanaan dan pengendalian dimasa mendatang (Sufrin, 2017).

Terdapat beberapa penelitian terdahulu yang meneliti tentang pengaruh akuntansi pertanggungjawaban terhadap pengendalian biaya. Menurut penelitian Setiyanto (2017) menyatakan bahwa akuntansi pertanggungjawaban memiliki pengaruh positif signifikan terhadap pengendalian biaya. Menurut penelitian Nisak (2016) bahwa variabel akuntansi pertanggungjawaban yang terdiri atas struktur organisasi, perencanaan, pelaksanaan dan pelaporan secara simultan berpengaruh signifikan terhadap pengendalian biaya. Menurut penelitian Ardiani dan Wirasedana (2013) menyatakan bahwa akuntansi pertanggungjawaban memiliki pengaruh positif signifikan terhadap efektifitas pengendalian biaya. Menurut penelitian Anik (2013) menyatakan bahwa akuntansi pertanggungjawaban tidak berpengaruh dalam pengendalian biaya. Kelemahan dalam hasil penelitian tersebut karena belum adanya penggolongan biaya dan pemberian kode sehingga tidak dapat menilai kinerja perusahaan. Menurut Aliu (2013) bahwa akuntansi pertanggungjawaban tidak berpengaruh terhadap pengendalian biaya. Syarat-syarat akuntansi pertanggungjawaban belum efektif dilakukan oleh perusahaan tersebut karena masih berskala kecil. Dari beberapa hasil penelitian dapat disimpulkan bahwa masih terdapat perbedaan hasil penelitian terkait pengaruh akuntansi pertanggungjawaban terhadap pengendalian biaya, Sehingga Tujuan Penelitian ini adalah Untuk mengetahui pengaruh sistem perencanaan anggaran dalam akuntansi pertanggungjawaban, pelaksanaan pengendalian, sistem pelaporan terhadap pengendalian biaya.

Akuntansi pertanggungjawaban merupakan suatu sistem akuntansi yang menekankan pada tanggung jawab perorangan, baik dari tingkat manajemen atas, menengah maupun bawah. Untuk mencapai hal tersebut dibutuhkan suatu bentuk organisasi yang telah memisahkan secara jelas dan tegas wewenang dan tanggung jawab tiap-tiap pimpinan (Tarmizi, et al., 2010). Wewenang dan tanggungjawab yang dimaksud adalah dalam pengambilan keputusan atas biaya, pendapatan yang terjadi pada bagian yang dipimpinnya. Melalui pusat pertanggungjawaban manajemen menilai setiap pimpinan atas biaya-biaya terkendali yang menjadi tanggungjawabnya dengan cara membandingkan antara realisasi dengan anggarannya.

Akuntansi dan pengendalian biaya adalah sistem yang dirancang untuk mengumpulkan dan melaporkan biaya dengan tingkat individu dari tanggung jawab, setiap area pengawasan dibebankan hanya dengan biaya yang sangat bertanggung jawab dan lebih memiliki kontrol dalam menjalankan perusahaan (Siyanbola dan Raji, 2013). Cara ini dapat bekerja dengan baik dalam menunjukkan biaya-biaya keluar dan menentukkan siapayang bertanggung jawab dalam biaya-biaya yang dikeluarkan untuk mengambil tindakan korektif yang cepat.

Terdapat hubungan antara akuntansi pertanggungjawaban yang memadai dengan pengendalian biaya pada perusahaan. Dimana semakin baik akuntansi pertanggungjawaban maka akan semakin baik pula pengendalian biaya. Sedangkan pengendalian biaya yang baik akan memudahkan akunatansi pertanggungjawaban dalam perusahaan sehingga tujuan perusahaan akan dicapai (Ardiani dan Wirasedana, 2013).

Penerapan akuntansi pertanggungjawaban akan menghasilkan informasi akuntansi pertanggungjawaban yang dihubungkan dengan wewenang yang dimiliki tiap-tiap manajer. Dengan adanya wewenang dan tanggungjawab yang jelas pada tiap-tiap tingkatan manajemen maka akan memudahkan manajemen dalam menilai pelaksanaan yang dicapai perusahaan dengan cara membandingkan anggaran yang telah ditetapkan dengan realisasi biaya yang sebenarnya (Ardiani dan Wirasedana, 2013). Dalam penelitian ini terdapat dua jenis variabel yaitu Variabel bebas dan terikat, terdapat empat variabel bebas dengan simbol (X1-X4) dan satu variabel terikat dengan simbol (y), kerangka hubungan antar variabel seperti pada Gambar 1.

\section{Hipotesis}

Hipotesis merupakan jawaban sementara atau kesimpulan sementara terhadap permasalahan yang menjadi objek penelitian yang kebenarannya masih perlu diuji secara empiris. 
Ho: Tidak terdapat pengaruh Struktur organisasi, Perencanaan Anggaran, Pelaksanaan Anggaran, dan Pelaporan terhadap Pengendalian Biaya pada BLU RSUD Manokwari.
H1: Terdapat Pengaruh Struktur organisasi, Perencanaan Anggaran, Pelaksanaan Anggaran, dan Pelaporan terhadap Pengendalian Biaya Biaya pada BLU RSUD Manokwari.

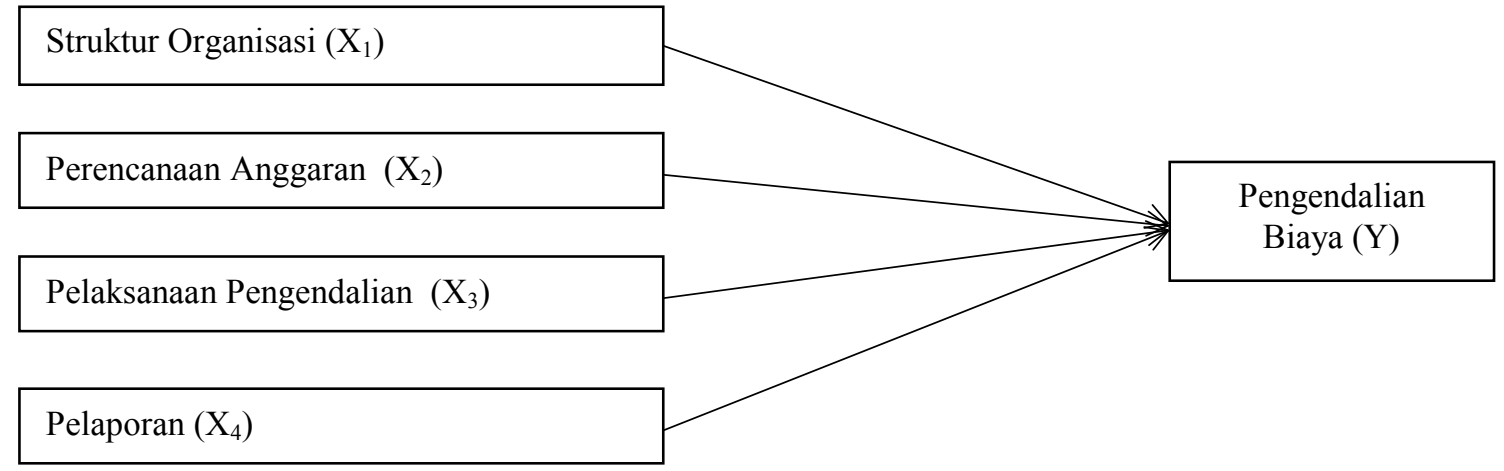

Keterangan : $>=$ Merpengaruhi

Gambar 1. Kerangka Berpikir

\section{METODE PENELITIAN}

Menurut Sugiyono (2009) pengertian objek penelitian adalah sasaran ilmiah untuk mendapatkan data dengan tujuan dan kegunaan tertentu tentang sesuatu hal objektif dan reliabel tentang suatu hal (variabel tertentu). Objek dalam penelitian ini adalah Rumah Sakit Umum Daerah (RSUD) Manokwari. Waktu penelitian pada tanggal 15 Desember 2018 sampai dengan 7 Februari 2019.

\section{Populasi}

Populasi adalah wilayah generalisasi yang terdiri atas : objek/subjek yang mempunyai kualitas dan karakteristik tertentu yang ditetapkan oleh peneliti untuk dipelajari dan kemudian ditarik kesimpulan, Sugiyono (2011). Populasi dalam penelitian ini adalah Direktur, Kepala Bidang Keuangan, Seksi Verifikasi dan Akuntansi,

\section{Jenis Data dan Sumber Data}

Jenis data yang digunakan dalam penelitian ini yaitu jenis penelitian kuantitatif. Menurut Widoyoko (2012), metode kuantitatif merupakan metode yang data penelitiannya berwujud angkaangka sebagai hasil observasi atau pengukuran. Sumber data yang digunakan dalam penelitian ini adalah data primer. Data primer adalah data yang diperoleh secara langsung dari sumber
Seksi Perbendaharaan dan Anggaran, dan Staf Administrasi berjumlah 66 orang (Tabel 1).

\section{Sampel}

Sampel merupakan bagian dari jumlah dan karakteristik yang dimiliki oleh populasi tersebut (Sugiyono, 2009). Dalam penelitian ini, teknik pengambilan sampel yang digunakan adalah metode sampling jenuh atau sensus. Sampel jenuh atau sensus adalah teknik pengambilan sampel dimana semua populasi dijadikan sebagai sampel (Sujarweni, 2016).

Tabel 1. Populasi

\begin{tabular}{lc}
\hline \multicolumn{1}{c}{ Jabatan } & Jumlah \\
\hline Direktur & 1 \\
\hline Kepala Bidang Keuangan & 1 \\
\hline Seksi Verifikasi dan Anggaran & 1 \\
\hline Seksi Perbendaharaan dan Akuntansi & 1 \\
\hline Staf Administrasi & 62 \\
\hline Total & $\mathbf{6 6}$ \\
\hline aslinya (Indriantoro dan Supomo, 2011). Data \\
primer dalam penelitian ini diperoleh secara \\
langsung melalui cara menyebar kuesioner \\
kepada responden.
\end{tabular}

\section{Teknik Pengumpulan Data}

Teknik pengumpulan data yang digunakan dalam penelitian ini adalah dengan teknik kuesioner. Kuesioner merupakan teknik 
pengumpulan data yang dilakukan dengan cara memberi seperangkat pertanyaan atau pertanyaan tertulis kepada responden untuk dijawabnya , Sugiyono (2011) Kuesioner diadopsi oleh Wijayani (2014) kemudian dikembangkan oleh peneliti sesuai dengan objek penelitian.

\section{Metode Analisis Data}

\section{Uji Validitas}

Uji ini digunakan untuk mengukur sah atau valid tidaknya suatu kuesioner. Suatu kuesioner dikatakan valid jika pertanyaan pada kuesioner tersebut mampu mengungkapkan sesuatu yang akan diukur oleh kuesioner tersebut (Ghozali, 2011). Pengujian ini dilakukan dengan menggunakan teknik bivariate correlation pada software Statical Package for Social Science (SPSS) 21 yang dijalankan dengan menggunakan media komputer. Kuisioner dikatakan valid apabila memiliki nilai signifikansinya $<0,05$.

\section{Uji Reliabilitas}

Uji reliabilitas adalah alat yang digunakan untuk mengukur suatu kuesioner yang merupakan indikator dari suatu variabel. Kuesioner dikatakan reliabel atau handal jika jawaban seseorang terhadap pernyataan adalah konsisten atau stabil dari waktu ke waktu (Ghozali, 2011).Suatu variabel dikatakan reliabel atau handal apabila mempunyai nilai Cronbach's Alpha $>0,60$. Namun menurut Guilford (1956) menyatakan bahwa koefisien reliabilitas mempunyai kategori sebagai berikut:

- $0,80<1,00$ reliabilitas sangat tinggi

- $0,60<0,80$ reliabilitas tinggi

- $0.40<0,60$ reliabilitas sedang

- $0,20<0,40$ reliabilitas rendah

- $-1,00<0,20$ reliabilitas sangat rendah (tidak reliabel)

\section{Uji Asumsi Klasik}

\section{Uji Normalitas}

Uji normalitas bertujuan mengetahui apakah dalam model regresi, variabel pengganggu atau residual memiliki distribusi normal atau tidak. Untuk mengetahui apakah data berdistribusi normal atau tidak, maka dapat dilakukan uji statistik Kolmogorov-Smirnov Test, dengan nilai signifikansi > 0,05 (Ghozali, 2011).

\section{Uji Multikolinieritas}

Uji multikolinieritas bertujuan untuk mengetahui apakah dalam model regresi ditemukan adanya korelasi antar variabel bebas (independen). Uji multikolinieritas dilakukan dengan dua cara yaitu dengan melihat VIF (Variance Inflation Factor) dan nilai tolerance. Jika VIF $<10$ dan nilai tolerance $>0,10$ maka tidak terjadi gejala multikolinearitas (Ghozali, 2011).

\section{Uji Heteroskedastisitas}

Uji heteroskedastisitas bertujuan untuk menguji apakah dalam model regresi terjadi ketidaksamaan variance dari residual satu pengamatan ke pengamatan yang lain (Ghozali, 2011). Jika suatu variance dari residual satu pengamatan ke pengamatan yang lainnya tetap, maka disebut homoskesdastisitas dan jika terjadi perbedaan dengan pengamatan yang lain maka disebut heteroskedastisitas. Menurut Ghozali (2016) untuk mengetahui ada tidaknya heteroskedastisitas dalam penelitian dapat dilihat dengan Uji Glejser SPSS, jika signifikansi > 0,05 maka dapat disimpulkan bahwa tidak terjadi heteroskedastisitas.

\section{Analisis Regresi Berganda}

Analisis regresi berganda yaitu menambah jumlah variabel bebas yang sebelumnya hanya satu variabel menjadi dua atau lebih variabel bebas (Sanuri, 2013). Tujuan dari analisis regresi linear berganda untuk mengetahui apakah variabel independen berhubungan positif ataukah negatif terhadap variabel dependen.

Persamaan regresi linear berganda adalah : $\mathrm{Y}=$ $\alpha+\beta_{1} \cdot \mathrm{X}_{1}+\beta_{2} \cdot \mathrm{X}_{2}+\beta_{3} \cdot \mathrm{X}_{3}+\beta_{4} \cdot \mathrm{X}_{4}+\mathrm{e}$

Keterangan :

$$
\begin{array}{ll}
\mathrm{Y} & =\text { Pengendalian Biaya } \\
\alpha & =\text { Konstanta } \\
\beta & =\text { Koefisien Regresi } \\
\mathrm{X}_{1} & =\text { Struktur Organisasi } \\
\mathrm{X}_{2} & =\text { Perencanaan Anggaran } \\
\mathrm{X}_{3} & =\text { Pelaksanaan Pengendalian } \\
\mathrm{X}_{4} & =\text { Pelaporan } \\
\mathrm{e} & =\text { Standar Error }
\end{array}
$$

Jika nilai probabilitas signifikansi $<0,05$ maka H0 diterima. Artinya bahwa variabel independen tidak berpengaruh signifikan terhadap variabel dependen. Sedangkan jika nilai probabilitas signifikansi $>0,05$ maka $\mathrm{Ha}$ diterima. Artinya bahwa variabel independen 
berpengaruh signifikansi terhadap variabel dependen.

\section{HASIL DAN PEMBAHASAN}

\section{Partisipasi Responden}

Jumlah responden yang berpatisipasi dalam penelitian ini adalah 66 orang. Dari 66 kuesioner yang disebarkan, 60 kuesioner yang diterima kembali dan 6 kuesioner tidak kembali dengan alasan responden tidak berada di tempat.

Tabel 2. Hasil Penyebaran Kuesioner

\begin{tabular}{lcc}
\hline Keterangan & Jumlah & Persentase \\
\hline $\begin{array}{l}\text { Kuesioner yang } \\
\text { dikembalikan }\end{array}$ & 60 & $91 \%$ \\
\hline $\begin{array}{l}\text { Kuesioner yang tidak } \\
\text { dikembalikan }\end{array}$ & 6 & $9 \%$ \\
\hline $\begin{array}{l}\text { Total kuesioner yang } \\
\text { disebarkan }\end{array}$ & 66 & $100 \%$ \\
\hline
\end{tabular}

Sumber : Data primer diolah (2019)

\section{Analisis Statistik Deskriptif}

Variabel Struktur Organisasi $\left(\mathrm{X}_{1}\right)$ memiliki nilai minimum sebesar 20 dan nilai maximum sebesar 30 dengan nilai mean sebesar 23,93, nilai standar deviasi 2,291 dan variance 5,250. Variabel Perencanaan Anggaran $\left(\mathrm{X}_{2}\right)$ memiliki nilai minimum sebesar 15 dan nilai maximum sebesar 24 dengan nilai mean sebesar 19,13, nilai standar deviasi 1,961 dan variance 3,846.

Variabel Pelaksanaan Pengendalian $\left(\mathrm{X}_{3}\right)$ memiliki nilai minimum sebesar 25 dan nilai maximum sebesar 38 dengan nilai mean sebesar 30,58, nilai standar deviasi 3,038 dan variance 9,230 . Variabel Pelaporan $\left(\mathrm{X}_{4}\right)$ memiliki nilai minimum sebesar 22 dan nilai maximum sebesar 35 dengan nilai mean sebesar 28,43, nilai standar deviasi 2,825 dan variance 7,979. Variabel Pengendalian Biaya (Y) memiliki nilai minimum sebesar 32 dan nilai maximum sebesar 50 dengan nilai mean sebesar 40,93 , nilai standar deviasi 4,294 dan variance 18,436 .

Tabel 3. Hasil Analisis Statistik Deskriptif

\begin{tabular}{lcccccc}
\hline Varibel & N & Min & Max & Mean & Std. Dev & Variance \\
\hline Struktur Organisasi $\left(\mathrm{X}_{1}\right)$ & 60 & 20 & 30 & 23.93 & 2.291 & 5.250 \\
\hline Perencanaan Anggaran $\left(\mathrm{X}_{2}\right)$ & 60 & 15 & 24 & 19.13 & 1.961 & 3.846 \\
\hline Pelaksanaan Pengendalian $\left(\mathrm{X}_{3}\right)$ & 60 & 25 & 38 & 30.58 & 3.038 & 9.230 \\
\hline Pelaporan $\left(\mathrm{X}_{4}\right)$ & 60 & 22 & 35 & 28.43 & 2.825 & 7.979 \\
\hline Pengendalian Biaya $(\mathrm{Y})$ & 60 & 32 & 50 & 40.93 & 4.294 & 18.436 \\
\hline Valid N (listwise) & 60 & & & & & \\
\hline
\end{tabular}

Sumber : Data primer diolah (2019)

\section{Uji Kualitas Data}

\section{Uji Validitas}

Setelah dilakukan pengujian ternyata beberapa butir pertanyaan yang tidak valid pada kuesioner yang telah disebar, sebagaimana terdapat pada variabel Y. Namun untuk melanjutkan ke tahap pengujian selanjutnya maka peneliti menghapus beberapa butir pertanyaan yang tidak valid tersebut. Semua pertanyaan pada setiap variabel adalah valid dan nilai tingkat signifikansinya $<$ 0,05 , sehingga dapat dikatakan layak digunakan.

\section{Uji Reliabilitas}

Semua variabel bersifat reliabel (Tabel 4). Variabel Pelaksanaan Pengendalian $\left(\mathrm{X}_{3}\right)$ dan Pengendalian Biaya (Y) memiliki nilai Cronbrach's Alpha > 0,60, termasuk dalam kategori $0,60-0,80$ (reliabilitas tinggi).. Variabel Perencanaan Anggaran $\left(\mathrm{X}_{2}\right)$ memiliki nilai Cronbrach's Alpha $<0,60$ dan termasuk dalam kategori 0.40 - 0,60 sehingga dapat dikatakan reliabilitas sedang. Variabel Struktur Organisasi $\left(\mathrm{X}_{1}\right)$ dan Pelaporan $\left(\mathrm{X}_{4}\right)$ ) memiliki nilai Cronbrach's Alpha $<0,60$ dan termasuk kategori 0,20 - 0,40 (reliabilitas rendah).

Tabel 4. Hasil Uji Reliabilitas

\begin{tabular}{lcc}
\hline \multicolumn{1}{c}{ Variabel } & Cronbrach Alpha & Keterangan \\
\hline Struktur Organisasi $\left(\mathrm{X}_{1}\right)$ & 0,382 & Reliable Rendah \\
\hline Perencanaan Anggaran $\left(\mathrm{X}_{2}\right)$ & 0,424 & Reliable Sedang \\
\hline Pelaksanaan Pengendalian $\left(\mathrm{X}_{3}\right)$ & 0,618 & Reliable Tinggi \\
\hline Pelaporan $\left(\mathrm{X}_{4)}\right.$ & 0,390 & Reliable Rendah \\
\hline Pengendalian Biaya $(Y)$ & 0,705 & Reliable Tinggi \\
\hline Sumber : Data primer yang diolah (2019) & &
\end{tabular}




\section{Uji Asumsi Klasik}

\section{Uji Normalitas}

Uji normalitas bertujuan mengetahui apakah dalam model regresi, variabel pengganggu atau residual memiliki distribusi normal atau tidak. Untuk mengetahui apakah data berdistribusi normal atau tidak, maka dapat dilakukan uji Tabel 5. Uji Normalitas

\begin{tabular}{|c|c|c|}
\hline \multicolumn{3}{|c|}{ Unstandardized Residual } \\
\hline $\mathrm{N}$ & & 60 \\
\hline \multirow{2}{*}{ Normal Parameters ${ }^{\mathrm{a}, \mathrm{b}}$} & Mean & $0 \mathrm{E}-7$ \\
\hline & Std. Deviation & 3.88471624 \\
\hline \multirow{3}{*}{ Most Extreme Differences } & Absolute & .077 \\
\hline & Positive & .077 \\
\hline & Negative & -.047 \\
\hline Kolmogorov-Smirnov Z & & .596 \\
\hline Asymp. Sig. (2-tailed) & & .870 \\
\hline
\end{tabular}

\section{Uji Multikolineritas}

Hasil pengujian (Tabel 6) menunjukkan bahwa setiap variabel independen memiliki nilai VIF $<$ 10 dan nilai tolerance $>0,10$, maka dapat statistik Kolmogorov-Smirnov Test, dengan nilai signifikansi $>$ 0,05 (Ghozali, 2011). Hasil uji normalitas dapat dilihat pada Tabel 5 .

Nilai Kolmogorov-Smirnov Z Test adalah 0,596 dan nilai pada signifikansi sebesar 0,870 lebih besar dari 0,05. Sehingga dapat dinyatakan bahwa data berdistribusi normal. disimpulkan bahwa tidak terdapat gejala multikolinieritas antar variabel independen dalam model regresi.

Tabel 6. Uji Multikolinieritas

\begin{tabular}{lccl}
\hline \multirow{2}{*}{ Model } & \multicolumn{2}{c}{ Collinearity Statistics } & \multirow{2}{*}{ Keterangan } \\
\cline { 2 - 3 } & Tolerance & VIF & \\
\hline Struktur Organisasi $\left(\mathrm{X}_{1}\right)$ & 0,890 & 1,124 & Tidak terjadi multikolinieritas \\
\hline Perencanaan Anggaran $\left(\mathrm{X}_{2}\right)$ & 0,972 & 1,029 & Tidak terjadi multikolinieritas \\
\hline Pelaksanaan Pengendalian $\left(\mathrm{X}_{3}\right)$ & 0,872 & 1,146 & Tidak terjadi multikolinieritas \\
\hline Pelaporan $\left(\mathrm{X}_{4}\right)$ & 0,950 & 1,053 & Tidak terjadi multikolinieritas \\
\hline
\end{tabular}

Sumber : Data primer diolah (2019)

\section{Uji Heteroskedastisitas}

Berdasarkan hasil analisis (Tabel 7), nilai signifikan Struktur Organisasi sebesar 0,718, Perencanaan Anggaran sebesar 0,812, Tabel 7. Uji Heteroskedastisitas

\begin{tabular}{lcl}
\hline \multicolumn{1}{c}{ Variabel } & Signifikan & Keterangan \\
\hline Struktur Organisasi $\left(\mathrm{X}_{1}\right)$ & 0,718 & Homokedastistas \\
\hline Perencanaan Anggaran $\left(\mathrm{X}_{2}\right)$ & 0,812 & Homokedastistas \\
\hline Pelaksanaan Pengendalian $\left(\mathrm{X}_{3}\right)$ & 0,162 & Homokedastistas \\
\hline Pelaporan $\left(\mathrm{X}_{4}\right)$ & 0,542 & Homokedastistas \\
\hline Sumber : Data primer diolah (2019) & &
\end{tabular}

Pelaksanaan Pengendalian sebesar 0,612, dan Pelaporan sebesar 0,542. Maka kelima variabel tersebut menjelaskan bahwa tidak terjadi heteroskedastisitas.

\section{Analisis Regresi Berganda}

Tujuan dari analisis regresi linear berganda untuk mengetahui apakah variabel independen berhubungan positif ataukah negatif terhadap variabel dependen.

Berdasarkan Tabel 8, diperoleh persamaan regresi sebagai berikut :

$\mathrm{Y}=29,173-0,492 \mathrm{X}_{1}+0,433 \mathrm{X}_{2}+0,068 \mathrm{X}_{3}+$ $0,463 \mathrm{X}_{4}+\mathrm{e}$
Bentuk persamaan diatas memberikan gambaran regresi sebagai berikut :

1. Nilai dari konstanta sebesar 29,173 menyatakan bahwa variabel bebas dianggap konstan, maka nilai dari pengendalian biaya adalah 29,173.

2. Struktur Organisasi $\left(X_{1}\right)$ mempunyai nilai koefisien regresi sebesar 0,492 dan bernilai negatif, yang berarti apabila terjadi peningkatan terhadap variabel Struktur 
Organisasi maka pengendalian Biaya akan berkurang sebesar 0,492.

3. Perencanaan Anggaran $\left(\mathrm{X}_{2}\right)$ mempunyai nilai koefisien regresi sebesar 0,433 dan bernilai positif, yang berarti apabila terjadi peningkatan terhadap variabel Perencanaan Anggaran maka Pengendalian Biaya akan bertambah sebesar 0,433.

4. Pelaksanaan Pengendalian $\left(\mathrm{X}_{3}\right)$ mempunyai nilai koefisien regresi sebesar 0,068 dan bernilai positif, yang berarti apabila terjadi peningkatan terhadap variabel Pelaksanaan Pengendalian maka Pengendalian Biaya akan bertambah sebesar 0,068 .
5. Pelaporan $\left(\mathrm{X}_{4}\right)$ mempunyai nilai koefisien regresi sebesar 0,463 dan bernilai positif, yang berarti apabila terjadi peningkatan terhadap variabel Pelaksanaan Pengendalian maka Pengendalian Biaya akan bertambah sebesar 0,463 .

\section{Uji Simultan (Uji F)}

Berdasarkan hasil uji statistik (Tabel 9), nilai probabilitas signifikan sebesar 0,024 , dan jauh lebih kecil dari 0,05 sehingga dapat disimpulkan secara simultan variabel Struktur Organisasi, Perencanaan Anggaran, Pelaksanaan Pengendalian dan Pelaporan berpengaruh terhadap Pengendalian Biaya.

Tabel 8. Hasil Analisis Regresi Berganda

\begin{tabular}{|c|c|c|c|c|c|c|}
\hline \multirow{2}{*}{\multicolumn{2}{|c|}{ Model }} & \multicolumn{2}{|c|}{ Unstandardized Coefficients } & \multirow{2}{*}{$\frac{\text { Standardized Coefficients }}{\text { Beta }}$} & \multirow[t]{2}{*}{$\mathrm{t}$} & \multirow[t]{2}{*}{ Sig. } \\
\hline & & $\mathrm{B}$ & Std. Error & & & \\
\hline \multirow{5}{*}{1} & (Constant) & 29.173 & 8.965 & & 3.254 & .002 \\
\hline & $\mathrm{X}_{1}$ & -.492 & .242 & -.263 & -2.030 & .047 \\
\hline & $\mathrm{X}_{2}$ & .433 & .271 & .198 & 1.598 & .116 \\
\hline & $\mathrm{X}_{3}$ & .068 & .185 & .048 & .370 & .713 \\
\hline & $\mathrm{X}_{4}$ & .463 & .190 & .305 & 2.432 & .018 \\
\hline
\end{tabular}

Sumber : Sumber : Data primer diolah (2019)

Tabel 9. Uji Simultan (Uji F)

\begin{tabular}{|c|c|c|c|c|c|c|}
\hline & Model & Sum of Squares & Df & Mean Square & $\mathrm{F}$ & Sig. \\
\hline \multirow{3}{*}{1} & Regression & 197.363 & 4 & 49.341 & 3.048 & $.024^{\mathrm{b}}$ \\
\hline & Residual & 890.370 & 55 & 16.189 & & \\
\hline & Total & 1087.733 & 59 & & & \\
\hline
\end{tabular}

Sumber : Sumber : Data primer diolah (2019)

\section{Uji Parsial (Uji t)}

Berdasarkan uji statistik pada Tabel 10, diperoleh hasil pengujian hipotesis secara parsial untuk setiap variabel independen sebagai berikut

1. Variabel Struktur Organisasi $\left(X_{1}\right)$ mempunyai $t$ hitung sebesar $-2,030$ dengan nilai signifikan 0,047 . Oleh karena nilai signifikan lebih kecil dari 0,05 , maka dapat dikatakan bahwa variabel Struktur Organisasi berpengaruh secara signifikan terhadap pengendalian biaya. Sehingga dapat dikatakan hipotesis pertama diterima.

2. Variabel Perencanaan Anggaran $\left(X_{2}\right)$ mempunyai $t$ hitung sebesar 1,598 dengan nilai signifikan 0,116 . Oleh karena nilai signifikan lebih besar dari 0,05 , maka dapat dikatakan bahwa variabel Perencanaan Anggaran tidak berpengaruh secara signifikan terhadap pengendalian biaya. Sehingga dapat dikatakan hipotesis kedua ditolak.

3. Variabel Pelaksanaan Pengendalian $\left(X_{3}\right)$ mempunyai $\mathrm{t}$ hitung sebesar 0,370 dengan nilai signifikan 0,713 . Oleh karena nilai signifikan lebih besar dari 0,05 , maka dapat dikatakan bahwa variabel Pelaksanaan Pengendalian tidak berpengaruh secara signifikan terhadap pengendalian biaya. Sehingga dapat dikatakan hipotesis ketiga ditolak.

4. Variabel Pelaporan $\left(\mathrm{X}_{4}\right)$ mempunyai t hitung sebesar 2,432 dengan nilai signifikan 0,018. Oleh karena nilai signifikan lebih kecil 0,05, maka dapat dikatakan bahwa variabel Pelaporan berpengaruh secara signifikan terhadap pengendalian biaya. Sehingga dapat dikatakan hipotesis keempat diterima. 
Tabel 10.1 Uji Parsial (Uji t)

\begin{tabular}{|c|c|c|c|c|c|c|}
\hline \multirow{2}{*}{\multicolumn{2}{|c|}{ Model }} & \multicolumn{2}{|c|}{ Unstandardized Coefficients } & \multirow{2}{*}{$\frac{\text { Standardized Coefficients }}{\text { Beta }}$} & \multirow[t]{2}{*}{$\mathrm{t}$} & \multirow[t]{2}{*}{ Sig. } \\
\hline & & $\mathrm{B}$ & Std. Error & & & \\
\hline \multirow{5}{*}{1} & (Constant) & 29.173 & 8.965 & & 3.254 & .002 \\
\hline & $\mathrm{X}_{1}$ & -.492 & .242 & -.263 & -2.030 & .047 \\
\hline & $\mathrm{X}_{2}$ & .433 & .271 & .198 & 1.598 & .116 \\
\hline & $\mathrm{X}_{3}$ & .068 & .185 & .048 & .370 & .713 \\
\hline & $\mathrm{X}_{4}$ & .463 & .190 & .305 & 2.432 & .018 \\
\hline
\end{tabular}

Sumber : Data primer diolah (2019)

\section{Uji Koefisien Determinasi $\left(\mathbf{R}^{2}\right)$}

Berdasarkan hasil uji statitstik pada Tabel 11, nilai Asjusted R Square adalah sebesar 0,122, yang artinya $12,2 \%$ variabel dependen yaitu Pengendalian Biaya dapat dijelaskan oleh variabel independennya yaitu Struktur
Organisasi, Perencanaan Anggaran, Pelaksanaan Pengendalian, Pelaporan. Sedangkan sisanya $87,8 \%$ dijelaskan oleh variabel lain diluar penelitian ini atau tidak dimasukkan dalam model.

Tabel 11. Uji Koefisien Determinasi $\left(\mathbf{R}^{2}\right)$

\begin{tabular}{lrrrr}
\hline \multicolumn{5}{c}{ Model Summary } \\
\hline Model & $\mathrm{R}$ & R Square & Adjusted R Square & Std. Error of the Estimate \\
\hline 1 & $.426^{\mathrm{a}}$ & .181 & .122 & 4.023 \\
\hline
\end{tabular}

a. Predictors: (Constant), Pelaporan, Perencanaan Anggaran, Struktur Organisasi, Pelaksanaan Pengendalian

Sumber: Data primer diolah (2019)

\section{Pengaruh Struktur Organisasi terhadap Pengendalian Biaya}

Berdasarkan hasil pengujian pada hipotesis secara parsial (uji t) sebagaimana yang terdapat pada Tabel 10, variabel Struktur Organisasi $\left(\mathrm{X}_{1}\right)$ mempunyai $t$ hitung sebesar $-2,030$ dengan nilai signifikansi sebesar 0,047 , dalam hal ini nilai signifikansi dari variabel Struktur Organisasi $0,047<0,05$. Maka dapat di simpulkan bahwa variabel Struktur Organisasi berpengaruh signifikan terhadap Pengendalian Biaya. Hal ini menunjukkan bahwa salah satu unsur penting dalam akuntansi pertanggungjawaban adalah struktur organisasi. Struktur organisasi menunjukkan bahwa setiap pimpinan jelas atas segala kegiatan yang berada di bawah pengendaliannya. Melihat struktur organisasi yang telah ditetapkan oleh RSUD Manokwari sudah efektif dilakukan. Karena struktur organisasi RSUD terbagi atas unit-unit layanan, tugas-tugas yang dibebankan kepada setiap unit kerja organisasi digolongkan secara jelas dan pelaksanaanpun terawasi. Hasil penelitian ini sejalan dengan penelitian yang dilakukan oleh Setiyanto dan Norafyana (2017) dan Nisak (2016) yang menyatakan bahwa dalam penerapan akuntansi pertanggungjawaban meliputi struktur organisasi dapat berpengaruh terhadap pengendalian biaya.

\section{Pengaruh Perencanaan Anggaran terhadap Pengendalian Biaya}

Variabel Perencanaan Anggaran $\left(\mathrm{X}_{2}\right)$ mempunyai t hitung sebesar 1,598 dengan nilai signifikansi sebesar 0,116 , dalam hal ini nilai signifikansi dari variabel Perencanaan Anggaran $0,116>0,05$. Maka dapat di simpulkan bahwa variabel Perencanaan Anggaran tidak berpengaruh signifikan terhadap Pengendalian Biaya. Hal ini menunjukkan bahwa perencanaan anggaran dalam akuntansi pertanggungjawaban belum dapat diterapkan pada RSUD Manokwari. Hal ini menunjukkan bahwa semakin tinggi perencanaan anggaran tidak memengaruhi pengendalian biaya. Hasil penelitian ini sejalan dengan Nisak (2016) yang menyatakan bahwa dalam penerapan akuntansi pertanggungjawaban meliputi perencanaan anggaran tidak berpengaruh terhadap pengendalian biaya. Hasil penelitian ini tidak sejalan dengan Setiyanto dan Norafyana (2017) yang menyatakan bahwa dalam penerapan akuntansi pertanggungjawaban meliputi perencanaan anggaran dapat berpengaruh terhadap pengendalian biaya.

\section{Pengaruh Pelaksanaan Pengendalian terhadap Pengendalian Biaya}

Hasil pengujian pada hipotesis secara parsial (uji t) sebagaimana yang terdapat pada Tabel 10 menunjukan bahwa variabel Pelaksanaan Pengendalian $\left(\mathrm{X}_{3}\right)$ mempunyai $\mathrm{t}$ hitung sebesar 
0,370 dengan nilai signifikansi sebesar 0,713 , dalam hal ini nilai signifikansi dari variabel Pelaksanaan Pengendalian 0,713 >0,05. Maka dapat di simpulkan bahwa variabel Pelaksanaan Pengendalian tidak berpengaruh signifikan terhadap Pengendalian Biaya. Hal ini menunjukkan bahwa semakin tinggi atau rendahnya pelaksanaan pengendalian tidak memengaruhi pengendalian biaya, dikarenakan dilihat dari setiap pertanggungjawaban mungkin tidak konsisten dalam mengendalikan biaya. Hasil penelitian ini sejalan dengan penelitian yang dilakukan oleh Setiyanto dan Norafyana (2017) dan Nisak (2016) yang menyatakan bahwa dalam penerapan akuntansi pertanggungjawaban meliputi pelaksanaan pengendalian tidak berpengaruh terhadap pengendalian biaya.

\section{Pengaruh Pelaporan terhadap Pengendalian Biaya}

Variabel Pelaksanaan Pengendalian $\left(\mathrm{X}_{4}\right)$ mempunyai t hitung sebesar 2,432 dengan nilai signifikansi sebesar 0,018 , dalam hal ini nilai signifikansi dari variabel Pelaporan 0,018< 0,05 . Maka dapat di simpulkan bahwa variabel Pelaporan berpengaruh signifikan terhadap Pengendalian Biaya. Hal ini menunjukkan bahwa salah satu unsur penting dalam akuntansi pertanggungjawaban adalah laporan pertanggungjawaban. Laporan pertanggungjawaban berisi informasi yang berguna bagi pengambilan keputusan direktur. Laporan pertanggungjawaban biaya disajikan untuk memungkinkan setiap direktur melakukan pengelolaan biaya. Hasil penelitian ini sejalan dengan Setiyanto dan Norafyana (2017) dan Nisak (2016) yang menyatakan bahwa dalam penerapan akuntansi pertanggungjawaban meliputi pelaporan dapat berpengaruh signifikan terhadap pengendalian biaya.

\section{KESIMPULAN}

Berdasarkan hasil penelitian yang diuraikan diatas, maka terdapat kesimpulan sebagai berikut :

1. Struktur organisasi secara signifikan berpengaruh terhadap pengendalian biaya. Hal ini menunjukkan bahwa struktur organisasi telah diterapkan pada RSUD Manokwari, sehingga dapat berpengaruh terhadap pengendalian biaya.

2. Perencanaan anggaran secara signifikan tidak berpengaruh terhadap pengendalian biaya.
Hal ini menunjukkan bahwa semakin tinggi perencanaan anggaran tidak mempengaruhi pengendalian biaya.

3. Pelaksanaan pengendalian secara signifikan tidak berpengaruh terhadap pengendalian biaya. Hal ini menunjukkan bahwa semakin tinggi atau rendahnya pelaksanaan pengendalian tidak mempengaruhi pengendalian biaya.

4. Pelaporan secara signifikan berpengaruh terhadap pengendalian biaya. Hal ini menunjukkan bahwa pelaporan telah diterapkan pada RSUD Manokwari, sehingga dapat berpengaruh terhadap pengendalian biaya.

\section{Keterbatasan Penelitian}

Adapun keterbatasan penelitian ini adalah:

1. Dalam penelitian ini peneliti menggunakan kuesioner yang berupa pertanyaan tertulis dan tidak melakukan wawancara terstruktur, sehingga kemungkinan responden tidak memahami pertanyaan dan asal menjawab.

2. Jumlah variabel dan sampel yang terbatas, sehingga hasil interpretasi mungkin tidak dapat digeneralisasi.

\section{DAFTAR PUSTAKA}

Aliu, S. 2013. Penerapan Akuntansi Pertanggungjawaban sebagai Pengendalian Biaya Produksi Dan Penilaian Kinerja. Jurnal EMBA Vol. 1 No.3 : 160-168.

Anik, A. P. 2013. Evaluasi Penerapan Akuntansi Pertanggungjawaban sebagai Alat Pengendalian Biaya Produksi. Jurnal EMBA Vol. 1 No.4 : 1667-1676.

Anthony, Robert $\mathrm{N}$ and Vijay Govindarajan. 2001. Management Control System. Edition tenth. Mc. Graw Hill companies inc., New York. Diterjemahkan oleh F.X. Kurniawan Tjakrawala. Buku 1. Jakarta: Salemba Empat.

Ardiani, N. M. S., dan I. W. P. Wirasedana. 2013. Pengaruh Penerapan Akuntansi Pertanggungjawaban terhadap Efektifitas Pengendalian Biaya. E- Jurnal Akuntansi Universitas Udayana 5.3 : 561-573.

Bidang, Handrinal. 2013. Penerapan Akuntansi Pertanggungjawaban sebai Alat Pengendalian Biaya pada PT. Telkomsel 
Regional Sulawesi dan Papua. Universitas Hasanudin Makassar. Tidak diterbitkan.

Ghozali, I. 2011. Aplikasi Analisiss Multivariate Dengan Program IBM SPSS 19 (edisi kelima). Semarang: Universitas Diponegoro.

Ghozali, I. 2016. Aplikasi Analisiss Multivariate Dengan Program SPSS. Badan Penerbit Universitas Diponegoro.

Horngren, C. T., S. M. Datar, and G. Foster. 2008. Akuntansi Biaya Penekanan Manajerial. Erlangga: Yogyakarta.

Indriantoro, Nur dan Bambang Supomo. 2011, Metodologi Penelitian Bisnis untuk Akuntansi dan Manajemen, Edisi Pertama. BPFE, Yogyakarta.

Juita, R. K. 2014. Analisis Akuntansi Pertanggungjawaban. Jurnal Bisnis, Manajemen \& Ekonomi.

Kreitner, R., and A. Kinicki. 2014. Perilaku Organisasi. Salemba Empat: Jakarta Selatan.

Lubia, A. I. 2010. Akuntansi Keperilakuan. Salemba Empat: Jakarta Selatan.

Mulyadi. 1990. Akuntansi Biaya. Edisi Ke-4. Yogyakarta. BPFE

Mulyadi. 1997. Akuntansi Manajemen : Konsep, Manfaat, dan Rekayasa. Edisi ke-2. Yogyakarta : Bagian Penerbitan Sekolah Tinggi Ilmu Ekonomi YKPN.

Mulyadi. 2001. Akuntansi Manajemen : Konsep, manfaat dan Rekayasa. Edisi ke- 3. Jakarta. Salemba Empat

Mulyadi. 2014. Akuntansi Biaya. UPP STIM YKPN: Yogyakarta.

Mulyadi. 2016. Sistem Akuntansi. Salemba Empat: Jakarta Selatan.

Nazir, Moh. 2005. Metode Penelitian. Jakarta: Ghalia Indonesia.

Peraturan Menteri Dalam Negeri No. 61 Tahun 2007 tentang Pedoman Teknis Pengelolaan Keuangan Badan Layanan Umum Daerah

Peraturan Pemerintah Republik Indonesia No.23 Tahun 2005 tentang Pengelolaan Keuangan Badan Layanan Umum.

Rosidah, E., and C. Krisnadi. 2008. Peranan Anggaran Biaya Produksi dalam
Menunjang Efektifitas Pengendalian Biaya Produksi. Jurnal Akuntansi FE Unsil Vol. 3 No. $1: 8-20$.

Samryn. LM., 2001. Akuntansi Manajerial Suatu Pengantar. Edisi Pertama. Cetakan Kedua. Jakarta: PT. Raja Grafindo Persada.

Samryn L.M. 2012. Akuntansi Manajemen : Informasi Biaya Untuk Mengendalikan Biaya Aktivitas Operasi \& Investasi. Edisi Pertama, Penerbit : Kencana, Jakarta.

Sanuri, A. 2013. Metodologi Penelitian Bisnis. Jakarta: Salemba Empat.

Setiyanto, A. I. 2017. Pengaruh Penerapan Akuntansi Pertanggungjawaban terhadap Pengendalian Biaya pada Industri Manufaktur di Batam. Jurnal Riset Akuntansi Vol 06, No. 01 : 43-50.

Simammora Henry. 2012. Akuntansi Manajemen. Edisi III, Penerbit : Star Gate Pulisher, Yogyakarta.

Siregar, B., B. Supripto, D. Hapsoro, E. W. Lo, E. Herowati, dan L. Kusumasari. 2013. Akuntansi Biaya. Salemba Empat:Jakarta.

Siyanbola, T. T., and G. M. Raji 2013. The Impact Of Cost Control On Manufacturing Industries Profitability. Internasional Journal of Management and Social Science Research Vol 2 , No. 4 : 1-7.

Sufrin, M.I. 2017, Penerapan Akuntansi Pertanggungjawaban sebagai Alat Pengendalian Biaya pada RSUD Bahteramas Provinsi Sulawesi Tenggara. Tidak diterbitkan.

Sugiyono. 2009, Metode Penelitian Kuantitatif, Kualitatif, dan $R \& D$. Cetakan Pertama ke6. Bandung : Alfabeta.

Sugiyono. 2011, Metode Penelitian Kuantitatif, Kualitatif, dan $R \& D$. Bandung : alfabeta.

Supriyono, 1999. Akuntansi biaya. BPFEYOGYAKARTA: Yogyakarta.

Tarmizi, R., M. Selvyana, dan A. Purnomo. 2010. Pengendalian Biaya dalam Hubungannya dengan Akuntansi Pertanggungjawaban. Jurnal Akuntansi \& Keuangan Vol. 1, No. 1 : 95-108.

Tin, S., dan T. Hidayat. 2012. Analisis Pengaruh Penerapan Akuntansi 
Pertanggungjawaban terhadap Kinerja Manajer Pusat Laba di Warung Paskal Bandung. Jurnal Akuntansi Vol. 4 No.2 : 187-199.
Wijayani, A. R. 2014. Pengaruh Akuntansi Pertanggungjawaban terhadap Pengendalian Biaya Standar. Jurnal Akuntansi Universitas Negeri Yogyakarta : 1-15. 